\title{
The Use of Land to Generate Political Support
}

\author{
Ato Kwamena Onoma*
}

\section{Introduction}

On the 14th of October 2005, President Mwai Kibaki of Kenya vowed 'I will go to Olenguruone tomorrow to issue title deeds to the members of the Ogiek community as all plans have been finalized by the Ministry of Lands' (The Standard 15 October 2005). The President kept his word and distributed 12,000 land title deeds to members of the Ogiek community the next day (The Standard 17 October 2005). This is interesting because the Ogiek had, earlier that year, been evicted from the Mau forest complex by Kibaki's state agents who assaulted many so-called squatters and burnt down homes, schools and even clinics in a bid to discourage them from returning. Further, the president blatantly disobeyed a Nakuru High Court injunction against the issuance of those title deeds (The Standard 17 October 2005).

Given the fact that Kenyans, displaced during clashes around the 1992 and 1997 elections, had yet to be resettled, the stubborn generosity of the president is bewildering. But these were no ordinary times in Kenyan politics. Mwai Kibaki was leading a Banana (Ndizi) campaign team seeking a 'Yes' vote in a referendum for a proposed constitution in November of that year. Opposing the passage of the new constitution was an Orange (Chungwa) campaign team led by many members of Kibaki's own government like Raila Odinga and Kalonzo Musyoka as well as leading members of the opposition Kenya African National Union (KANU). Many opponents and civil society activists perceived the issuance of titles at Olenguruone as part of the widespread distribution of 'campaign freebies' (The Standard 17 October 2005). These freebies also included the creation of many new districts and handover of the famous Ambroseli National Park to the Masai community under the Olkejuado County Council, to the anger and wild protestation of the Kenya Wildlife Service responsible for managing the park (The Standard 31 October 2005).

* Department of Political Science, Yale University, New Haven, Connecticut, USA.Email: kwamena_onoma@yahoo.com, ato.onoma@yale.edu. 
The use of land to generate political support has received considerable attention, as many African countries have re-adopted multiparty democracy (Klopp 2000:82; Addison and Laakso 2003:458-59). This use of land to garner support should come as little surprise in a context where governments, as well as opposition politicians, are known to 'buy' votes in cash and kind. As many African states control land in parts of their national territories, land is another of the public resources used to further private political ambitions. This redistribution of land during electioneering should not be necessarily seen in a negative light. Democratic pressures on leaders to redistribute land in countries with highly inequitable distributions could help alleviate the landlessness and land hunger plaguing many in such societies.

In this paper, I place the use of land to garner political support in a broader perspective and examine the institutional implications of this exchange of land for support. What institutional arrangements facilitate these political exchanges? What are the wider social implications of these mediating institutional structures?

I argue that one of the more pernicious effects of the use of land to generate electoral support is that it depends on an environment in which the power to guarantee land rights is placed in the arbitrary hands of politicians and removed from autonomous and predictable institutions such as courts, deeds registries and councils of elders. I highlight two reasons why such an institutional environment is critical. First, it gives politicians the ability to punish people who accept land but fail to render political support. It is this ability that gives politicians the confidence that people will engage in proper political behaviour once they get the land. It is also what gives voters the ability to convince politicians of their intent to stick by their promise to engage in 'appropriate political behaviour' once they receive the land. Second, it allows politicians to perform the delicate task of gerrymandering constituencies without redrawing boundaries.

The problem is that, while such an institutional environment is useful for these political exchanges, it is fundamentally harmful to the wider society in many ways. It breeds uncertainty that can lead to the loss of life and property by many as people contest over uncertain land rights. Uncertainty over rights can disempower the weakest members of society by tying them to bosses who provide them with security (Addison and Laakso 2003:459). Furthermore, uncertainty and unpredictability can discourage many from undertaking certain long term investments in land.

\section{Using Land to Garner Support}

The exchange of land for political support seems to be a widespread practice in contemporary Africa. Politicians use land rights to reward followers, buy 
the support of would-be opposition members and punish opponents. Nigerian parliamentarian, Uche Onyeagucha, alleged the existence of an extensive scheme to convince Nigerian parliamentarians to support the failed bid by President Obasanjo to change the constitution to allow for a third presidential term in 2006 by offering MPs land parcels in Abuja (BBC News 9 May 2006 and 15 May 2006). In Ghana, Kwamena Bartels, Minister for Private Sector Development and the President's Special Initiatives of the New Patriotic Party (NPP), in the guise of promoting agricultural activity announced a plan in September 2005 to award hundred-acre parcels to ministers and MPs. A public outcry thwarted this plan (Ghanaweb 21 September 2005 and 26 September). Ntsebeza has roundly criticized the ANC's passage of laws that increased chiefs' powers over the allocation of rural land. He sees this ceding of rights over land partly as an effort by the ANC to court the support of chiefs who are sometimes strong enough in their local domains to influence how people vote (Ntsebeza 2005:269). There have been widespread allegations that President Mugabe has transformed land redistribution programs into instruments for rewarding supporters, winning over opponents and punishing reluctant opposition members and supporters. It is alleged that, while close supporters of the president receive land, many landhungry peasants have not seen any benefits from these programs. Furthermore, it is argued that white settlers have been targeted for expropriation because they are friendly to the opposition Movement for Democratic Change (MDC) (Good 2002:12-18; Addison and Laakso 2003:459).

It is tempting to regard the exchange or land for political support as another dimension of the pathologies of contemporary African politics. Klopp falls into this tempting trap in 'Pilfering the public'. But neither the favouring of government supporters in land distribution programs nor the exchange of land for political support is new. Colonial governments in countries like Kenya, Zimbabwe, Namibia, Australia, New Zealand and South Africa expropriated large tracts of lands from indigenous populations for the use of friendlier and more supportive European settler communities. These then contributed tax revenues to the colonial enterprise and participated in efforts at subjugating these communities. Members of the Pioneer Column were thus given land in Zimbabwe (then Southern Rhodesia) for their contribution to the subjugation of African resistance in the colony (Worby 2001:480).

The workings of British colonial rule in Ghana (the former Gold Coast) provide evidence of the use of land to cultivate support by colonial authorities. Faced with the challenge of governing the territory cheaply, the British used land as a key instrument to buy the support of traditional chiefs and enable them to control their subjects on behalf of the state. The arbitrary recognition 
and suspension of the rights of chiefs was used by colonial officials to get chiefs to act as the adjuncts of the British within the system of indirect rule (Asante 1975:40-47). Troublesome chiefs like the Asantehene that dared resist, had their land rights summarily suspended (Bentsi-Enchill 1964:19). Compliant chiefs could count on the British to reinforce and even magnify their rights over land. This included the fabrication of various 'traditional' norms governing customary tenure that quashed all challenges to the rights of chiefs to act as custodians of land (Asante 1975:40-47; Mamdani 1996:2123). This reinforcement of customary tenure, even in the face of obvious evolution towards individual freehold forms in certain areas, was also an attempt to reinforce the powers of chiefs over their subjects to facilitate rule. Phillips notes in this regard that the colonial official/anthropologist Capt. Rattray, in arguing against reforms aimed at diminishing the powers of chiefs over land, pointed out that 'it was the responsibility of the colonial states to prevent them [Africans] escaping from the control of tribal authorities' (Phillips 1989:122).

The point I wish to make here is that the exploitation of property rights in land to cultivate and sustain political support, and discourage and punish opposition is far more widespread than many of the recent denunciations of Zimbabwean or Kenyan leaders' political exploitation of land suggest. It is neither a very recent practice characterizing the return to multiparty democracy in Africa nor a preserve of corrupt African leaders. Land as an important resource is a key instrument of political control and important cause of political contestation (Shivji 2006; Berry 2001:19; Kanyinga 1996, 2000).

\section{An Enabling Institutional Environment}

A key disconcerting effect of the exchange of land for political support is the environment of uncertainty over land rights that facilitates such arrangements, and which politicians often actively seek to create. By an environment of uncertainty, I mean an environment where the security of property rights ceases to depend on the workings and decisions of autonomous institutions that determine the location and extent of rights, adjudicate disputes over rights and enforce decisions concerning rights to land. These institutions take various forms. They could take the form of village committees and councils of elders that allocate land, keep information on the existence and extents of land interests and adjudicate and enforce land disputes. They could also take the form of land commissions, land courts, title and deeds registries and special enforcement agencies. For instance, the postcolonial state in Botswana under the BDP passed the Tribal Land Act (1968) to create land boards that assumed powers over customary land previously held by chiefs. These land boards and subordinate land boards allocate land, adjudicate land 
dispute, record and document land interest and also engage in land use planning (Kalabamu and Morolong 2004:48-58). Pursuant to the Tribal Land (Establishment of Land Tribunals) Order, Statutory Instrument No. 59 of 1995, a land tribunal was created in 1997 as a specialized court that dealt with appeals against the decisions of land boards (Kalabamu and Morolong 2004:58-60). The state also created two web-based land information systems: the State Lands Information Management System (SLIMS) and the Tribal Land Information Management System (TLIMS) to improve geographical information available to state officials and the public. ${ }^{1}$

Where these institutions work well, they take the guarantee of land rights away from the arbitrary whims of politicians. The location and dimensions of one's plot of land would be determined by councils of elders and cadastral maps instead of the local parliamentarian. Similarly, a competent tribunal using evidence from elders, title registers, maps and field visits will decide who has a more convincing case in a land dispute, instead of the secretary to the president. Whether the rights claimed by someone would be protected by police will be decided by tribunals and land administration agencies instead of an aspiring parliamentarian with a strong influence on the local police chief. The point is not that all will have equal access to land under the reign of these institutions, but that whether one has access to rights will be determined by laid down procedures by competent parties. As the highly discriminative land tenure regimes deployed by colonial administration in South Africa, Namibia, Zimbabwe and Kenya indicate, the security of property rights and well-functioning title registries and land tribunals should not be obfuscated with equal access to land right by all. These institutions often underpin and calcify the theft of land by dominant groups as is evident in various parts of Latin America, Australia, New Zealand and the United States. But where land rights are equitable, they can also protect the weak from predation by more powerful parties.

Why are these proper-functioning autonomous institutions problematic and have to be undermined in order for the exchange of votes to be successful? They are problematic precisely because they protect the weak from predation by powerful politicians. First, they could lead to a failure in the political market for land. Take the example of a local politician Masego who has control over land that he wants to exchange for votes in an upcoming election. On the other side of the potential bargain is Neo, a landless voter who has a vote that she would like to sell for a parcel of land. Even where both parties would like to transact, the existence of proper functioning institutions that protect the land rights of Neo might prevent the two from undertaking the exchange. If Neo knows that her rights are secure, then she would be able to 'sell' her vote to Masego and receive the land. Since her rights to the land 
would be secure and untouchable by Masego once she gets the land, she could then go ahead and refuse to vote for and attend rallies organized by Masego. She might even then 'sell' her vote once again to Masego's opponent. Knowing this, Masego will hesitate to give Neo the land parcel for her vote. Put differently, the presence of strong institutions that guarantee property rights will inflict on both parties an inability to credibly commit to certain future behaviour that will render the transaction attractive to both of them. Masego cannot credibly commit to punish Neo for deviance once she receives the land. Neo cannot credibly commit to supply the vote once she gets the land.

In an environment where the guarantee of Neo's right rests in the hands of the politician Masego, the problem will be solved. Masego will be able to credibly threaten Neo with eviction and repossession of the land if she refuses to attend campaigns, wear T-shirts with certain engravings, and if she is suspected of not voting for Masego. Neo will be able to commit to render support once she gets the land.

Politicians understand these institutional needs of their exchange of land for political support. Senior British colonial officials in Ghana routinely overruled appeals for the creation of title registries and land tribunals by reformminded but politically naïve junior colonial officers who thoroughly detested what they saw as the disruptive effects of chiefs' control over land (Phillips 1989:127; Berry 2001:10-20; Meek 1949:172-173). The senior colonial officials who overruled these reforms were wise. If they had transferred the power to guarantee chiefs rights to land to title registries and independent tribunals, rebellious chiefs would have had nothing to fear from colonial district officials and provincial commissioners. It would have fundamentally undermined the system of indirect rule.

In a similar bid to seize the power to guarantee rights in a bid to facilitate the exchange of land for loyalty, the Kenyan Minister of Local Government, William ole Ntimama is reported to have declared boldly in the early 1990s that land titles were 'mere pieces of paper' (Weekly Review 9 July 1993). Ole Ntimama was facing Gikuyu residents of his Narok North Constituency who were thought to be opposed to his parliamentary bid and the presidential bid of his KANU party in the 1992 elections. To make his offer of the peaceful enjoyment of their lands in exchange for their political quiescence or loyalty work, he had to impress it on them that he, not land titles, would ultimately decide who would reside in Narok North. At the instigation of leading politicians like ole Ntimama and Nicholas Biwott many title-bearing Gikuyu people were subsequently violently evicted from their lands because of their perceived opposition to KANU around the 1992 and 1997 elections (The Commission 1999). 
Beyond facilitating the exchange of land for votes, politicians find their arbitrary control of the power to guarantee rights in land useful because it allows them to gerrymander constituencies even in situations where they lack the formal power to redraw constituency boundaries. The fundamental goal of gerrymandering is to make the voting complexion of a constituency more favourable to certain parties. But redrawing constituency boundaries is not the only means of achieving this. You could also just evict unwanted voters and move in sympathetic ones while maintaining existing boundaries. This involves arbitrarily cancelling the land rights of some and granting those rights to others. The land clashes around the 1992 and 1997 elections were partly efforts at gerrymandering without redrawing constituency boundaries. Luo, Luhya, Gikuyu among other populations thought of as sympathetic to opposition parties were violently evicted from areas in Narok, Uasin Gishu, Nakuru, Kericho, Nandi, Laikipia and Trans Nzoia districts (Judicial Commission Report, Klopp 2002). Their lands were then occupied by others. Meanwhile, populations who were thought of as more sympathetic to KANU were moved into certain constituencies to reduce the advantage of opposition parties. The settlement of 318 Kalenjin families in Likia just before the 1997 elections was perceived by resident Gikuyu as an effort to swing the elections in the favour of KANU (IDMC 2006:13-20).

The social costs of such exploitation of land rights by politicians and the institutional environment that facilitates it can be very high. There are the obvious human costs of violent evictions and expropriation of properties. The clashes around Kenyan elections in 1992 and 1997 discussed in the preceding paragraph, left an estimated 1500 dead and 300,000 displaced (IDMC 2006:13). Many of those displaced by these clashes had not been resettled by 2005, when President Kibaki vowed to resettle the Ogiek victims of state evictions. An old victim of election evictions in the 1990s, Wanjiku Njoroge Rumiriti, had to adopt the desperate measure of taking the state to court to seek redress in October 2005 (Inter press service 2005). The fact that many clash victims abandoned their farms, some of which were destroyed during the clashes, was bound to have a negative impact on agricultural production for those years. Furthermore, the threat of eviction and uncertainty concerning land rights would force many Kenyans to think twice about investing in certain parts of the country given their own political inclinations and ethnic identities.

\section{Conclusion}

With the return of multiparty elections to many African countries, the role of land in generating political support has received much attention lately. This paper has done two things. First, it places the use of land to garner and 
reward political support in broader historical perspective. Placing it within its broader historical and spatial context, I showed that, like a lot of phenomena in contemporary African politics, it is not as much of a peculiar pathology of recent African politics, as we might be tempted to believe. Second, I explored the institutional foundations of the exchange of land for political support. Beyond clarifying the dynamics involved in this practice, this exercise enables us understand the crusade against institutions that guarantee property rights and the uncertainty that tends to go along with the exchange of land for political support. In doing this, I highlighted some of the social costs of this phenomena beyond the fact that in these political markets for land, parcels sometimes go to those who need them the least and those who are least likely to make productive use of them.

\section{Note}

1. Interview with an official of the Department of Lands, Gaborone, (Bots 9), 21 January 2004, and another official of the Department of Lands, Gaborone, (Bots 12), 22 January 2004.

\section{References}

Addison, T. and Laakso, L., 2003, 'The Political Economy of Zimbabwe's Descent into Conflict,' Journal of International Development 15, pp. 458-59.

Asante, S. K. B., 1975, Property Law and social Goals in Ghana, 1844-1966, Accra: Ghana Universities Press, pp. 40-47.

BBC News, 2006, 'Nigeria MP in Land-for-Vote claim’, 9 May, http://news.bbc.co.uk/ 2/hi/africa/4753303.stm (Accessed 15 January 2008).

BBC News, 2006, Nigeria probes third-term graft', 15 May, http://news.bbc.co.uk/ 2/hi/africa/4773647.stm (Accessed 15 January 2008).

Bentsi-Enchill, K., 1964, Ghana Land Law: an Exposition, Analysis and Critique, Legon: African Universities Press, p. 19.

Berry, S., 2001, Chiefs Know their Boundaries: Essays on Property, Power, and the past in Asante, 1896-1996, Cape Town: David Philip, pp. 10-20.

Ghanaweb.com, 2005, 'Free Farming Land for Ministers and MPs,' 21 September, http://www.ghanaweb.com/GhanaHomePage/News Archive/ artikel.php?ID=90582 (Accessed 2 January 2008).

Ghanaweb.com, 2007, 'Bartels Retracts Statements on Ministers and PSI,' 26 September. http://www.ghanaweb.com/GhanaHomePage/NewsArchive/ artikel.php?ID=90965 (Accessed 2 January 2008).

Good, K., 2002, 'Dealing with Despotism: the People and the Presidents,' in Henning Melber ed. Zimbabwe's Presidential Elections 2002, Uppsala: Nordiska Afrikainstitutet, pp. 12-18. 
Internal Displacement Monitoring Center (IDMC), 2006, “I am a refugee in my own country:' conflict-induced internal displacement in Kenya,' Geneva Switzerland, 19 December, pp. 13-20. http://www.internal-displacement.org/ 8025708F004BE3B1/(httpInfoFiles)/AF919E45D789BD0BC125724900350687/ \$file/Kenya\%20Special\%20Report\%20Dec06.pdf, (Accessed 4 June 2007).

Inter Press Service (Johannesburg), 2005, 'Kenya: land battle moves to the courts', 18 October, http://allafrica.com/stories/200510180661.html (Accessed 14 January 2008).

Kalabamu, F. and Morolong, S., 2004, Informal Land Delivery Processes and Access to Land for the Poor in Greater Gaborone, Botswana, Informal Land Delivery Processes in African Cities 3 (Birmingham: International Development Dept. School of Public Policy University of Birmingham, pp. 48-60.

Kanyinga, K., 2000, Re-distribution from above: the Politics of Land Rights and Squatting in Coastal Kenya, Research Report, no. 115, Uppsala: Nordiska Afrikainstitutet.

Kanyinga, K., 1996, Struggles of Access to Land: the Land Question, Accumulation, and Changing Politics in Kenya, IDS Working paper; no. 504, Nairobi, Kenya: Institute for Development Studies University of Nairobi. Klopp, Jacqueline, 2000, 'Pilfering the Public: The Problem of Land Grabbing in Contemporary Kenya,’ Africa Today 47 (2000-1).

Klopp, Jacqueline, 2002, 'Can Moral Ethnicity Trump Political Tribalism? The Struggle for Land and Nation in Kenya,' African Studies 61.

Mamdani, M., 1996, Citizen and Subject: Contemporary Africa and the Legacy of Late Colonialism, Princeton, N.J.: Princeton University, pp. 21-23.

Meek, Charles Kingsley, 1949, Land, Law and Custom in the Colonies, 2nd ed., London: Oxford University Press, pp. 172-173.

Ntsebeza, L., 2005, Democracy Compromised: Chiefs and the Politics of the Land in South Africa. Vol. 5, Afrika-Studiecentrum Series, Leiden: Brill, p. 269.

Phillips, A., 1989, The Enigma of Colonialism: British Policy in West Africa, London: James Currey, pp. 122 and 127.

Report of the Judicial Commission Appointed to Inquire into Tribal Clashes in Kenya, 1999, Nairobi: The Commission.

Report of the Commission of Inquiry into the Illegal/Irregular Allocation of Public Land, 2004, Nairobi: Republic of Kenya, p. 82.

Shivji, I., 2006, 'Lawyers in Neoliberalism: Authority’s Professional Supplicants or

Society’s Amateurish Conscience,' Codesria bulletins 3\&4.

The Standard (Nairobi), 2005, 'President in move to allay fears over land', 15 October.

The Standard (Nairobi), 2005, 'Kibaki Criticized over Ogiek Title Deeds', 17 October. The Standard (Nairobi), 2005, Ambroseli National Park Transfer Halted’, 31 October. Worby, E., 2001, 'A Redivided Land? New Agrarian Conflicts and Question in

Zimbabwe', Journal of Agrarian Change, 1 October, p. 480.

Weekly Review (Nairobi), 1993, 'The Indigenous and the Natives’, 9 July. 
